\title{
Control of Varroa jacobsoni in honey-bee colonies in Yugoslavia by fumigation with low doses of fluvalinate or amitraz
}

\author{
JM Kulinčević 1, TE Rinderer 2*, VJ Mladjan 3, \\ SM Buco 4
}

\author{
1 PKB RO Institute "Agroekomomik", Padinska skela, 11000 Belgrade; \\ 2 US Department of Agriculture, Agricultural Research Service Honey-Bee Breeding, \\ Genetics and Physiology Laboratory 1157 Ben Hur Road, Baton Rouge, LA 70820; \\ 3 Veterinary Institute, Vojvode Toze 14, 11000 Belgrade, Yugoslavia; \\ ${ }^{4}$ Statistical Resources Inc 7332 Highland Road, Baton Rouge, LA 70808, USA
}

(Received 10 December 1988; accepted 23 January 1991)

\begin{abstract}
Summary - Low doses of fluvalinate were tested for control of Varroa jacobsoni in honey bee (Apis mellifera) colonies in Yugoslavia. When presented to colonies as a smoke strip fumigant, low dosages ( $0.0025 \mathrm{~g}$ per colony on 3 occasions) provided excellent control of $V$ jacobsoni. In comparison with amitraz as a fumigant or in an aerosol or fluvalinate in an aerosol, the application of fluvalinate as a fumigant killed a greater percentage of mites. Mite mortality occurred mainly in the first 90 min after treatment but continued throughout the first $24 \mathrm{~h}$ after treatment at significant levels.
\end{abstract}

Apis mellifera / varroatosis / chemical control / fluvalinate / amitraz

\section{INTRODUCTION}

The honey bee (Apis mellifera $\mathrm{L}$ ) parasite Varroa jacobsoni Oudemans was first discovered in Yugoslavia in the middle 1970 's when it caused large losses of honey-bee colonies in the eastern parts of the country (Lolin, 1977). By the beginning of the 1980's all Yugoslavian beekeeping was troubled by the mite.

Various means for controlling $V$ jacobsoni infestations have been used in Yugo- slavia during the past decade. Recently, the most common method has been fumigation of colonies with amitraz (Varamit ${ }^{\circledR}$ ) (Kulinčević, 1985). Fumigation is accomplished by using smoldering paper strips containing a measured dose of amitraz and $\mathrm{NaNO}_{3}$. The $\mathrm{NaNO}_{3}$ causes the ignited paper to smolder and produce smoke which carries the toxicant throughout the hive. This treatment is effective with lower doses of toxicant applied in combination with increased temperatures and decreased humidities inside closed hives

\footnotetext{
* Correspondence and reprints

Mention of a proprietary compound or trademark name does not constitute an endorsement. This article reports research results and does not contain recommendations.
} 
(Kulinčević and Tomažin, 1986). However, most beekeepers in Yugoslavia use paper strips with $0.02 \mathrm{~g}$ of amitraz per hive several times a year. The hives have open entrances and the temperature and humidity are not altered.

Lately the synthetic pyrethroid fluvalinate has received considerable experimental attention (Koeniger and Chmielewski, 1986; Borneck and Merle, 1987; Vesely, 1987; Lubinevski et al, 1988). In the USA, fluvalinate in a plastic strip formulation (Apistan ${ }^{\circledR}$ ) is registered for use in bee colonies. Such a formulation was found to be effective in studies in Germany (Koeniger and Chmielewski, 1986) and in France (Borneck and Merle, 1987). A similar method was tested in Israel (Lubinevski et al, 1987), except instead of impregnated plastic, they used plywood soaked in Mavrik $^{\circledR}$, a formulation of fluvalinate registered in the United States for use on crops but not on bees.

These methods, especially the plywood method, use rather large amounts of active material that for best effect are present in hives for $\approx 3 \mathrm{wk}$. This is both costly and increases the possibility of contaminating hive products. Recently, in the United States, honey in bee hives was found to contain high residues of fluvalinate (H Shimanuki, personal communication). Also, these methods require the opening of colonies twice; first to insert and then later to remove the application devices. Consequently, we studied the effectiveness of low doses of fluvalinate applied in the form of paper smoke strips.

\section{MATERIALS AND METHODS}

For all experiments, we used honey-bee colonies of Apis mellifera carnica in standard Langstroth hives.

\section{Experiment 1: doses of fluvalinate}

Based on the dosages tested by Vesely et al (1987), 3 doses of active material $(0.0025 \mathrm{~g}$, $0.0035 \mathrm{~g}$, and $0.0075 \mathrm{~g}$ ) were compared. Using 30 colonies in an 18-d experiment, each dosage was applied using paper smoke strips placed on the bottom boards of 10 hives 3 times at 5-d intervals. The single chamber hives were maintained with opened entrances and were equipped with bottoms having screened removable inserts to permit the counting of dead mites. The hives contained colonies with $1.5-2 \mathrm{~kg}$ of bees. This experiment was carried out in the autumn when colonies were broodless.

Dead mites were counted on $d 1$ and 5 after each treatment application (d 2 and 6, 8 and 12 , 14 and 18 of the experiment). Data were submitted to multivariate profile analysis of variance (Bock, 1963; Neil, 1975) to determine differences between treatments, the effect of periodic applications of treatments and interactions between time effects and treatment dosages. The bees in one colony from the group receiving 3 applications of $0.0075 \mathrm{~g}$ of fluvalinate were killed and washed with ether to determine the number of live mites after treatment.

\section{Experiment 2: time required for mites to be killed by fluvalinate}

The second experiment measured the time required for mites to drop to screened bottom board inserts after application of fluvalinate as a fumigant. For this experiment, a single dose of $0.0035 \mathrm{~g}$ of fluvalinate was applied to each of 10 colonies in hives with 2 Langstroth hive bodies. The colonies had 4-6 kg of bees, queens, and brood. Colonies were treated in August 1987, after the nectar flow had stopped and honey had been removed.

Dead mites were counted from screened bottom board inserts at 30,60 and $90 \mathrm{~min}$ and 1 and $4 \mathrm{~d}$ after treatment. Multivariate profile analysis followed by univariate $F$-tests were used to determine the time when a plateau was reached in the number of mites killed (Bock, 1963; Neil, 1975). 


\section{Experiment 3: amitraz as a fumigant or aerosol and fluvalinate as a fumigant or aerosol}

The third experiment compared the mortality of mites following 4 different combinations of application procedure and toxicant material. Amitraz was applied to colonies both as a smoke strip (Varamit $\left.{ }^{(}\right)$containing $0.02 \mathrm{~g}$ of active material and as an aerosol containin $0.006 \mathrm{~g}$ of active material. Fluvalinate was applied as a smoke strip containing $0.0025 \mathrm{~g}$ of active material, and as an aerosol containing $0.0012 \mathrm{~g}$ of active material. Lower doses of active material were chosen for aerosols based on reports (Vesely, personal communication; Colin (1986) unpublished report, Varroa Workshop, Feldafing/Steinberg, Germany) that aerosol procedures required less toxicant.

Smoke strips were burned on top of the uppermost frames in hives with the entrances open and the covers in place. Aerosols were prepared as water dilutions of active material which were applied by an air-compression device "VAT-1", made in Czechosiovakia. During aerosol applications the hives were closed for 7-10 min.

Each combination of application procedure and materials was applied on a single occasion on d 1 of the experiment, Nov 13, 1987. Afterwards, on Dec 29-30 1987, and on Feb 27, 1988 , all colonies were fumigated with smoke strips containing $0.0025 \mathrm{~g}$ of fluvalinate. Dead mites were counted from screened bottom board inserts 1 and $7 \mathrm{~d}$ after each application of toxicant, ie $\mathrm{d} 2$ and 8,1016 , and 18 and 24 of the experiment.

Each of the combinations of materials and procedures was tested on 15 colonies. These colonies were typical field colonies housed in 2 Langstroth hive bodies. Colonies were large, with $4-6 \mathrm{~kg}$ of bees and contained queens but no brood. One colony from the group which was first treated with fluvalinate fumigation was killed and washed in ether to determine the total number of mites remaining after the 3 treatments.

Data were analyzed by a multivariate profile analysis of variance. The hypothesis concerning differences in the portion of the total dead mites killed by the initial applications of toxicant was tested by comparing the successive differences in numbers of dead mites. These profiles of changes through time were examined for parallel or non-parallel events. This multivariate test was followed by univariate Wilks' lambda tests to determine where non-parallel differences occurred.

\section{RESULTS AND DISCUSSION}

Fluvalinate, delivered to colonies in a smoke strip formulation, killed similar numbers of mites regardless of dose (table $\mathrm{I}$; $P<0.99$ ). More than $93 \%$ of the total mortality occurred after the first application. The second and third applications killed only a few additional mites $(3-5 \%$ and $0.7-$ $1.5 \%$, respectively).

The colony that was killed and examined in detail after treatment contained 2 mites. Thus, the lowest dose studied $(0.0025 \mathrm{~g})$ was effective in killing Varroa. Even lower doses might be demonstrated to be effective.

Experiment 2 (tracking mortality through time) demonstrated 3 characteristics of mite mortality following fluvalinate fumigation (fig 1). The majority of mites are killed within $90 \mathrm{~min}(P<0.0001)$; a significant increase in numbers of dead mites occurred between $90 \mathrm{~min}$ and $24 \mathrm{~h}(P<0.0005)$ and no significant increase in mite mortality occurred after $1 \mathrm{~d}(P<0.052)$, indicating that mite mortality quickly reached a plateau.

The rapid action of the fumigant procedure using fluvalinate is clear from this experiment. Also, we did not observe any side-effects from fluvalinate treatment on bees or queens.

In the comparison of combinations of application procedures and materials, $2 \mathrm{im}$ portant results were observed (fig 2). First, regardless of toxicant, the aerosol application procedure resulted in a smaller proportion of mites being killed when mortality was compared to subsequent mite mortality $(P<0.0001)$. Second, of the 4 combina- 
Table $I$. The cumulative numbers of dead mites $(X \pm S E)$ and the cumulative percentages of total dead mites per dosage and colony (in parentheses) following the application of 3 doses of fluvalinate as a fumigant from smoke strips given 3 times at 5-d intervals to 10 colonies each.

\begin{tabular}{|c|c|c|c|c|}
\hline \multirow{2}{*}{$\begin{array}{c}\text { Day of } \\
\text { Exp }\end{array}$} & \multirow{2}{*}{$\begin{array}{l}\text { Treatment } \\
\text { application }\end{array}$} & \multicolumn{3}{|c|}{ Treatment dosage } \\
\hline & & 0.0025 & 0.0035 & 0.0075 \\
\hline 1 & 1st treatment & & & \\
\hline 2 & & $\begin{array}{c}54.2 \pm 13.2 \\
(91.55)\end{array}$ & $\begin{array}{c}53.1 \pm 10.6 \\
(91.1)\end{array}$ & $\begin{array}{c}51.3 \pm 10.3 \\
(90.0)\end{array}$ \\
\hline 6 & & $\begin{array}{c}55.9 \pm 13.5 \\
(94.4)\end{array}$ & $\begin{array}{c}54.8 \pm 10.9 \\
(94.0)\end{array}$ & $\begin{array}{c}54.6 \pm 10.9 \\
(95.7)\end{array}$ \\
\hline 7 & 2nd treatment & & & \\
\hline 8 & & $\begin{array}{l}8.2 \pm 13.3 \\
(98.3)\end{array}$ & $\begin{array}{c}57.6 \pm 10.8 \\
(98.8)\end{array}$ & $\begin{array}{c}56.5 \pm 12.0 \\
(99.3)\end{array}$ \\
\hline 12 & & $\begin{array}{c}58.3 \pm 13.3 \\
(98.5)\end{array}$ & $\begin{array}{c}57.9 \pm 10.8 \\
(99.3)\end{array}$ & $\begin{array}{c}56.6 \pm 15.4 \\
(99.3)\end{array}$ \\
\hline 13 & 3rd treatment & & & \\
\hline 14 & & $\begin{array}{c}59.0 \pm 13.4 \\
(99.7)\end{array}$ & $\begin{array}{c}58.2 \pm 10.8 \\
(99.8)\end{array}$ & $\begin{array}{c}57.0 \pm 12.2 \\
(100)\end{array}$ \\
\hline 18 & & $\begin{array}{c}59.2 \pm 13.4 \\
(100)\end{array}$ & $\begin{array}{c}58.3 \pm 10.8 \\
(100)\end{array}$ & $\begin{array}{c}57.0 \pm 12.2 \\
(100)\end{array}$ \\
\hline
\end{tabular}

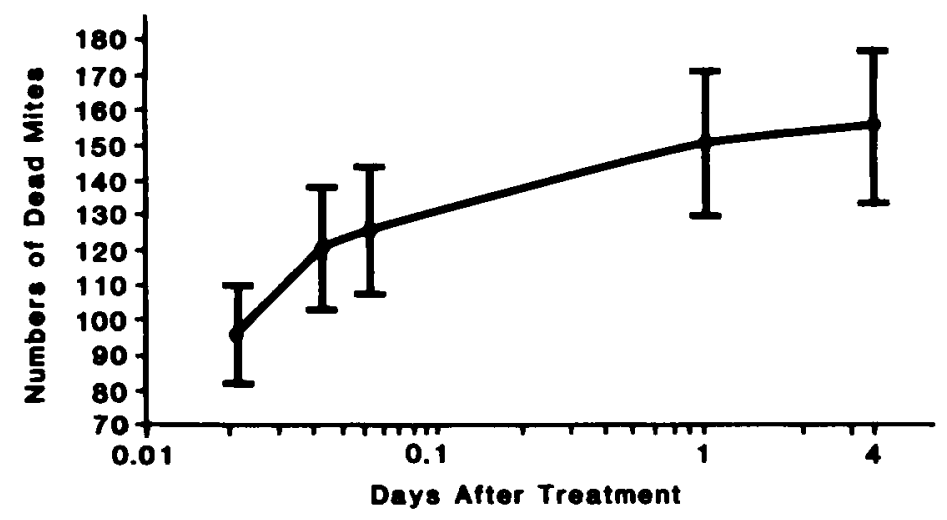

Fig 1. Total cumulative number $(X \pm S E)$ of mites killed through time after a single exposure to 0.0035 $g$ fluvalinate to each of 10 colonies.

tions of toxicants and procedures, the application of the fluvalinate fumigation procedure was followed by proportionally fewer dead mites resulting from subsequent treatments. Thus, the statistical analysis identified the fluvalinate fumigation group as different because of its flat profile $(P<$ $0.0001)$. The colony that was killed and ex- 


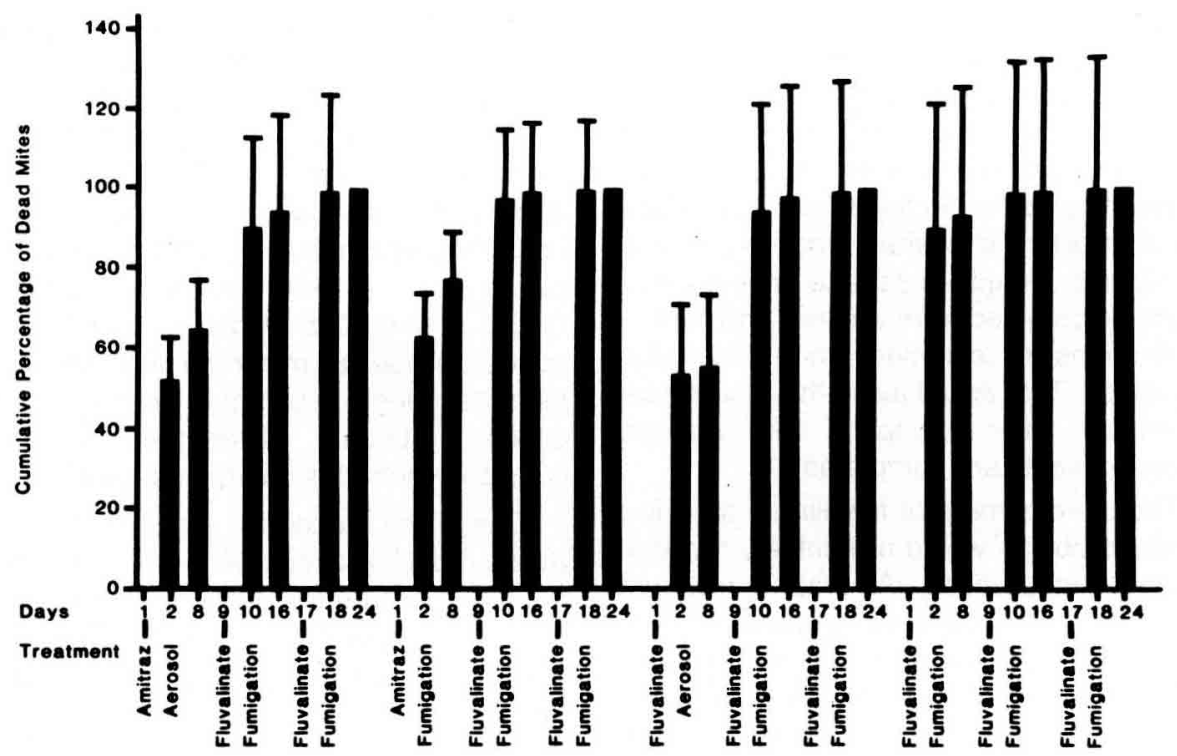

Fig 2. The cumulative percentage of dead $V$ jacobsoni mites in colonies first given amitraz, or fluvalinate, as a fumigant or an aerosol. In all cases the 2 nd and $3 r d$ treatments were with fluvalinate as a fumigant to determine the total mites in each of 15 colonies and hence assay the comparative efficiency of the 4 treatments first given to the colonies. Days indicate the cumulative days of the experiment. Bars indicate the average percentage of mite mortality; error bars are SE.

amined for mites remaining after treatment contained none.

In general, the aerosol application method gave poorer results. It may be that the smaller doses of toxicants used with this procedure are the source of the lesser efficiency. However, others have reported contrary experiences in comparisons of aerosols and fumigants (Evrat and Yakobson (1986), unpublished report, Symposium on Health Protection in Honey Bees, Zagreb, Yugoslavia).

The development of commercial fluvalinate fumigation procedures would provide an additional useful tool for controlling $V$ jacobsoni. The impregnated plastic strips and soaked plywood techniques (loc cit) provide the advantage of having a prolonged presence in the hive. This permits effective treatment of colonies, even when brood is present. Mites that parasitize newly emerging bees will be killed as long as the treatment remains in the colony. However, the prolonged exposure to toxicant increases the danger of the contamination of hive products, especially those containing wax. This is particularly true when hives are used that do not have separate compartments for honey production (honey supers) that can be removed during treatment. Bees in chest hives, drawer hives and similar equipment store honey and raise brood in all the hives combs, and thus these combs are a likely source of contaminated hive products. Fluvalinate fumigation would be a useful method of $V$ jacobsoni control in such hives. Also, some beekeepers might choose fumigation because of the convenience of the application procedures and the better control of 
dosage and timing of application. Unpredicted nectar flows occurring during application periods or mistakes of leaving treatments on colonies during nectar flows would not occur. However, fluvalinate fumigation is not expected to provide effective control of mites when brood is present in colonies. Nonetheless, adequate control might be obtained from autumn and winter applications of colonies when they are broodless. This would avoid the use of miticides until after the spring and summer honey harvests are completed.

The development of fluvalinate as a fumigant probably would not entirely replace amitraz preparations. Amitraz fumigation remains as an effective procedure. The control level it provided in experiment 2 is sufficient to maintain adequate colony health for commercial purposes. Also, the fumigation method with amitraz in Yugoslavia has not produced noticeable adverse effects on colonies, although it is reputed that other procedures with amitraz may lead to increased rates of queen supersedure (Lubinevski et al, 1988).

Because mite generations occur so rapidly, the general expectation is that fairly quickly, $V$ jacobsoni will develop resistance to any miticide. The alternate use of fluvalinate and amitraz may help to retard the development of resistance to toxicants in mite populations.

\section{ACKNOWLEDGMENTS}

This study was carried out in cooperation with the Louisiana Agricultura Experiment Station, and was financed by the office of United States Department of Agriculture, Office International Cooperation and Development's Special Foreign Currency Program and the YugoslavUnited States Joint Fund for Scientific and Technological Cooperation.

Résumé - Traitement de la varroatose dans les colonies d'abeilles en Yougo- slavie par fumigation de faibles doses de fluvalinate et d'amitraz. Les 3 expériences suivantes portent sur l'efficacité du fluvalinate en lanières fumigènes contre la varroatose (Varroa jacobsoni). Dans la $1^{\text {re }}$ expérience, nous avons comparé le nombre d'acariens tués par 3 répétitions de 3 dosages de matière active : $0,0025 \mathrm{~g}$, $0,0035 \mathrm{~g}$ et $0,0075 \mathrm{~g} /$ colonie. Tous les dosages ont tué au minimum $94 \%$ des acariens dans les 5 j suivant la première application. Aucune différence n'a été constatée entre les divers dosages.

Dans une seconde expérience, nous avons étudié le temps nécessaire à un traitement pour tuer les parasites. La majorité d'entre eux sont morts en $90 \mathrm{~min}(P<$ $0,0001)$. Néanmoins, un nombre supplémentaire important d'acariens sont morts dans les $24 \mathrm{~h}(P<0,005)$. Après $24 \mathrm{~h}$, la mortalité a stagné et seule une mortalité supplémentaire insignifiante a eu lieu ( $P<$ 0,052).

Dans la $3^{\theta}$ expérience, nous avons comparé le fluvalinate en fumigation à $0,0025 \mathrm{~g} /$ colonie et en aérosol à 0,0012 $\mathrm{g} /$ colonie avec l'amitraz en fumigation à $0,02 \mathrm{~g} /$ colonie et en aérosol à $0,006 \mathrm{~g} /$ colonie. Seul le fluvalinate en fumigation a réussi à tuer plus de $93 \%$ des acariens avec une seule application.

Une fois la mise au point faite, le fluvalinate en fumigation devrait constituer un outil supplémentaire utile dans la lutte contre $V$ jacobsoni. II offre la possibilité d'un dosage précis et du choix du moment pour l'application de l'acaricide. Une contamination accidentelle des produits du rucher, comme par exemple le nectar récolté, serait vraisemblablement réduite par un dosage précis, le choix du moment le plus opportun pour traiter, ainsi qu'une présence plus courte du produit dans la colonie.

Apis mellifera / varroatose / lutte chimique / fluvalinate / amitraze 
Zusammenfassung - Kontrolle von Varroa jacobsoni bei Bienenvölkern in Jugoslawien durch Räuchern von kleinen Dosen Fluvalinat und Amitraz. Nachfolgend werden drei Experimente über Aspekte der Wirkung von Fluvalinat in Form von Räucherstreifen bei der Kontrolle von Varroa jacobsoni beschrieben. Bei einem Experiment haben wir die Anzahl getöteter Milben nach drei Dosierungen von aktivem Material $(0.0025 \mathrm{~g}, 0.0035 \mathrm{~g}$ und $0.0075 \mathrm{~g} /$ Volk) in drei Wiederholungen verglichen. Alle Dosierungen töteten mindestens $94 \%$ der Milben innerhalb von fünf Tagen nach der ersten Anwendung. Zwischen den Dosierungen bestand kein Unterschied.

In einem weiteren Experiment untersuchten wir die Zeit, welche zur Abtötung der Milben nach der Behandlung erforderlich ist. Der größte Teil wurde innerhalb von 90 Minuten abgetötet $(P<0.0001)$. Eine erheblche zusätzliche Zahl ging jedoch innerhalb von 24 Stunden zugrunde $(P<0.0005)$. Nach 24 Stunden bildete die Mortalität ein Plateau und nachher ging nur noch eine geringe Anzahl Milben ein $(P<0.052)$.

In einem dritten Experiment verglichen wir Fluvalinat als Räuchermittel $(0.0025 \mathrm{~g} /$ Volk) und als Aerosol (0.0012 g/Volk) sowie Amitraz als Räuchermittel $(0.02 \mathrm{~g} /$ Volk) und als Aerosol (0.0006 g/volk). Die Fluvalinat-Räucherung übertraf alle anderen Anwendungen durch Abtötung von über $93 \%$ der Milben nach einer einzigen Behandlung.

Nach weiterer Ausarbeitung sollte sich die Fluvalinat-Räucherung als zusätzliches nützliches Mittel zur Kontrolle von $V$ jacobsoni erweisen. Sie bietet die Möglichkeit der exakten Dosierung und der Wahl des Zeitpunktes der Anwendung des Heilmittels. Die Möglichkeit einer unbeabsichtigten Kontaminierung der Bienenprodukte, wie zB des hereinkommenden Nektars, kann vermutlich durch eine präzisere Do- sierung, Wahl des geeignetesten Behandlungszeitpunktes sowie einer geringeren Verweildauer des Mittels im Volk verringert werden.

\section{Apis mellifera / Varroatose / chemische Kontrolle / Fluvalinat / Amitraz}

\section{REFERENCES}

Bock RD (1963) Multivariate analysis of variance of repeated measures. In: Problems of Measuring Change (Harris CW, ed) Univ of Wisconsin Press, Madison, WI, 85-103

Borneck R, Merle B (1987) New experiments of Varroa control with fluvalinate. In: Proc 31st Int Congr Apic 19-25 August 1987 Warsaw, Poland (Borneck, ed) 201-202

Koeniger N, Chmielewski M (1986) Anew approach to chemotherapy of varroatosis. In: European Research on Varroatosis Control. Proc EC Experts' Group, Bad Homburg (Germany), 15-17 October 1986 (Cavalloro R, ed) AA Balkema, Rotterdam, 231-236

Kulinčević JM (1985) II "Varamit" controlla con molto successo la varroasi in Yugoslavia. Apic Mod 76, 155-160

Kulinčević JM, Tomazin F (1986) Thermochemical control of Varroa jacobsoni with minimal application of amitraz. In: European Research on Varroatosis Control. Proc EC Experts' Group, Bad Homburg (Germany), 15-17 October 1986 (Cavalloro R, ed) AA Balkema, Rotterdam, 177-182

Lolin M (1977) Prvi slucaj varoatoze u našoj zemlji (First case of varroatosis in our country). Pcela 96, 24 (in Serbo-Croat)

Lubinevski $Y$, Yesshayahu S, Slabezki Y, Lensky Y, Ben-Yossef H, Gerson U (1988) Control of Varroa jacobsoni and Tropilaelaps clareae mites using Mavrik ${ }^{\circledR}$ in $A$ mellifera colonies under subtropical and tropical climates. Am Bee J 128, 48-52

Neil HT (1975) Multivariate Analysis with Applications in Education and Psychology. Wadsworth Publishing Co, Belmont, CA

Vesely V, Titera D, Mala J (1987) Pyrethroids in the control of Varroa disease. In: Proc 31st Int Congr Apic, 19-25 August 1987 Warsaw, Poland (Borneck, ed) 268-269 